\title{
Rehabilitasi Kardiovaskular pada Anak dengan Penyakit Jantung Bawaan
}

\author{
Agung Rizka Pratam ${ }^{1}$, Rita Hamdani', Citra Kiki Krevani \\ ${ }^{1}$ IImu Penyakit Jantung dan Pembuluh Darah, Universitas Andalas/RSUP Dr. Djamil, Jl. Perintis Kemerdekaan No.14, 25171. Padang, \\ Sumatera Barat, Indonesia \\ ${ }^{2}$ Bagian Kardiologi dan Kedoktertan Vasukular, Universitas Andalas/RSUP Dr. Djamil, Jl. Perintis Kemerdekaan No.14, 25171. Padang, \\ Sumatera Barat, Indonesia
}

A B S T R A C T

\begin{abstract}
Penyakit jantung bawaan merupakan kelainan komplek pada structural jantung. Banyak anak dengan penyakit jantung bawaan memiliki keterbatasan dalam beraktivitas diantaranya disebabkan oleh perubahan status gizi, termasuk tinggi dan berat badan serta kapasitas olahraga yang berkurang. Aktivitas fisik juga memiliki manfaat kesehatan otak untuk anak-anak, termasuk peningkatan fungsi kognitif dan berkurangnya gejala depresi. Bukti menunjukkan bahwa aktivitas fisik sedang hingga kuat meningkatkan fungsi kognitif dari memori, fungsi eksekutif, kecepatan pemrosesan, perhatian, dan prestasi akademik untuk anak-anak tersebut. Toleransi latihan olahraga atau aktivitas fisik anak-anak dengan berbagai bentuk PJB tergantung pada tingkat keparahan, keberhasilan prosedur korektif, munculnya serta derajat dari sisa penyakit sebelumnya. Namun hal ini bukan berarti membatasi anak dengan penyakit jantung bawaan untuk dapat melakukan latihan olahraga maupun aktivitas fisik. Program dan rekomendasi rehabilitasi kardiovaskular telah dipelajari secara luas pada pasien dengan penyakit jantung bawaan dengan pengawasan terintegrasi yang dilakukan oleh ahli jantung anak, dokter anak, ahli gizi, ahli terapi olahraga dengan terlebih dahulu dinilai kapasitas fungsional sebelum dilakukan rehabilitasi kardiovaskular.
\end{abstract}

Kata kunci: aktivitas fisik, kardiovaskular, latihan olahraga, penyakit jantung bawaan, rehabilitasi

Congenital heart disease is complex structural heart disorder. Many children with congenital heart disease have limitations in their activities due to changes in nutritional status, including height and weight and reduced exercise capacity. Physical activity also has brain health benefits for children, including improved cognitive function, and reduced anxiety and depression risk. Evidence shows that moderate to strong physical activity improves cognitive functions of memory, executive function, processing speed, attention, and academic achievement. Tolerance of sports training or physical activity of children with various forms of CHD depends on the severity,success of the corrective procedure, and residual sequelle. However, does not mean limiting of children with congenital heart disease to performing exercise training or physical activity. Cardiovascular rehabilitation programs and recommendations have been widely studied in patients with congenital heart disease with integrated supervision performed by pediatric cardiologists, pediatricians, nutritionists, sports therapists with prior assessment of functional capacity before cardiovascular rehabilitation. Keyword: rehabilitation, cardiovascular, congenital heart disease, physical activity, exercise training

\section{Apa yang sudah diketahui tentang topik ini?}

- Insidensi PJB adalah 4 hingga 8 per 1000 kelahiran hidup. Tanpa pengobatan, $60 \%$ pasien dengan PJB akan meninggal pada masa bayi, $25 \%$ pada periode neonatal, dan hanya $15 \%$ yang diperkirakan akan bertahan hidup hingga remaja dan dewasa

- Penyebab penurunan kapasitas olahraga pada pasien PJB mungkin terkait dengan perubahan hemodinamik, gangguan konduksi listrik, tekanan dan volume ventrikel yang berlebihan, perubahan aktivitas simpatovagal, peningkatan aktivitas neurohumoral, penurunan fungsi paru-paru dan perubahan metabolisme otot.

\section{Apa yang ditambahkan pada studi ini?}

Berkurangnya kapasitas olahraga dikaitkan dengan penurunan kualitas hidup pasien dengan PJB.8 Oleh karena itu, evaluasi kemampuan pasien PJB dapat memberikan informasi kesehatan penting terhadap sistem kardiopulmoner anak dan memberikan pengetahuan berharga tentang faktor-faktor yang mungkin membatasi kemampuan anak untuk melakukan aktivitas fisik 
CORRESPONDING AUTHOR

Phone: 081226607228

E-mail:doktertama@yahoo.com
ARTICLE INFORMATION

Received: July $3^{\text {rd }}$, 2020

Revised: April $18^{\text {th }}, 2021$

Available online: May $27^{\text {th }}, 2021$

\section{Pendahuluan}

Penyakit jantung bawaan (PJB) adalah penyakit dengan kelainan pada struktur jantung atau fungsi sirkulasi jantung yang dibawa dari lahir yang terjadi akibat adanya gangguan atau kegagalan perkembangan struktur jantung pada fase awal perkembangan janin. ${ }^{1}$ Insidensi PJB adalah 4 hingga 8 per 1000 kelahiran hidup. Tanpa pengobatan, $60 \%$ pasien dengan PJB akan meninggal pada masa bayi, $25 \%$ pada periode neonatal, dan hanya 15\% yang diperkirakan akan bertahan hidup hingga remaja dan dewasa. ${ }^{2}$ Adanya peningkatan pengetahuan dan teknologi medis selama beberapa dekade terakhir, secara dramatis meningkatkan angka kelangsungan hidup anak-anak dengan PJB. ${ }^{3}$ Saat ini, lebih dari 85\% dari semua pasien diharapkan hidup sampai dewasa. ${ }^{4}$ Sebuah studi cross-sectional multicenter pada tahun 2017 yang melibatkan total 798 anakanak (496 PJB dan 302 kontrol) yang menjalani tes latihan kardiopulmoner, ditemukan penurunan kebugaran fisik secara signifikan pada anak dengan PJB di bandingkan anak-anak normal. 5

Penyakit jantung bawaan dikaitkan dengan kelainan organik, baik sebelum maupun setelah dikoreksi secara operasi. Di antaranya disebabkan oleh perubahan status gizi, termasuk tinggi dan berat badan serta kapasitas olahraga yang berkurang. Dengan kemajuan dalam teknik bedah dan dukungan pasca operasi, terjadi peningkatan signifikan dalam angka kelangsungan hidup anakanak dengan PJB. Koreksi bedah pada PBJ telah berkontribusi pada peningkatan substansial dalam tingkat kelangsungan hidup pasien ini, menghasilkan kualitas hidup yang mendekati normal. Namun, tanda-tanda klinis dekompensasi seperti sianosis, dyspnoea dan perubahan nutrisi, serta penurunan kapasitas olahraga, dapat terjadi pada pasien, bahkan setelah koreksi bedah penyakit ini.6,7

Berkurangnya kapasitas olahraga dikaitkan dengan penurunan kualitas hidup pasien dengan PJB. ${ }^{8}$ Oleh karena itu, evaluasi kemampuan pasien PJB dapat memberikan informasi kesehatan penting terhadap sistem kardiopulmoner anak dan memberikan pengetahuan berharga tentang faktor-faktor yang mungkin membatasi kemampuan anak untuk melakukan aktivitas fisik. ${ }^{9}$ Rehabilitasi jantung untuk pasien dengan penyakit kardiovaskular yang didapat telah menjadi bagian dari perawatan rutin di banyak tempat selama bertahun-tahun. ${ }^{9}$

\section{Kapasitas Fungsional dan Aktivitas Fisik pada} Anak

Masa kanak-kanak adalah periode utama untuk mengembangkan keterampilan gerakan, mempelajari kebiasaan hidup sehat, dan membangun fondasi yang kuat untuk kesehatan. Aktivitas fisik yang teratur pada anak-anak dan remaja meningkatkan kesehatan dan kebugaran. Dibandingkan dengan mereka yang tidak aktif, anak muda yang aktif secara fisik memiliki tingkat kebugaran kardiorespirasi yang lebih tinggi dan otot yang lebih kuat. Aktivitas fisik juga memiliki manfaat kesehatan otak untuk anak-anak usia sekolah, termasuk peningkatan kesadaran dan berkurangnya gejala depresi. Bukti menunjukkan bahwa aktivitas fisik sedang hingga kuat meningkatkan fungsi kognitif dari memori, fungsi eksekutif, kecepatan pemrosesan, perhatian, dan prestasi akademik untuk anak-anak tersebut. ${ }^{10}$

Aktivitas fisik adalah kegiatan yang dilakukan setiap gerakan tubuh secara aktif yang dihasilkan dari kontraksi otot yang meningkatkan laju metabolisme di atas fase istirahat. Secara umum latihan yang berat didefinisikan sebagai aktivitas yang meningkatkan laju metabolisme hingga lebih dari enam kali laju istirahat. ${ }^{11}$ Anak-anak memiliki kebutuhan dasar untuk melakukan aktivitas fisik. Persepsi dan pengalaman motorik mereka tidak hanya menentukan perkembangan fisik dan motorik mereka tetapi juga dampak yang menentukan pada perkembangan emosi, psikososial, dan kognitif mereka. Sebaliknya, tidak melakukan aktivitas fisik pada masa kanak-kanak adalah abnormal - terlepas dari apakah itu disebabkan oleh faktor fisik, emosional, psikososial, atau kognitif. Karena itu, aktivitas fisik dan olahraga harus direkomendasikan dan dianjurkan untuk semua anak. ${ }^{12}$

Kapasitas fungsional dapat mengindikasikan disfungsi kardiovaskular, paru atau motorik. Pada 
anak-anak dengan penyakit kronis, konsumsi oksigen maksimal (VO2 max) dapat memprediksi hasil yang merugikan serta kebugaran aerobik yang lebih besar dikaitkan dengan pengurangan risiko hampir $10 \%$ untuk rawat inap anak-anak. Kapasitas fungsional bervariasi sesuai dengan jenis PJB, hasil bedah, usia dan jenis kelamin pasien. ${ }^{13}$ Pasien dengan perbaikan cacat jantung yang tidak lengkap menunjukkan penurunan yang signifikan dalam tingkat kerja puncak dan ventilasi maksimum yang disesuaikan usia dibandingkan dengan pasangan mereka yang menjalani perbaikan total. Kelainan jantung yang kompleks dan parah dapat (setidaknya untuk sementara) menyebabkan keterbatasan aktivitas fisik dan olahraga sehingga memerlukan sejumlah waktu istirahat dalam beraktifitas. Gambar 1 menunjukkan kemungkinan dampak penyebab dan efek ketidakaktifan fisik pada anak-anak dengan penyakit jantung. ${ }^{14}$

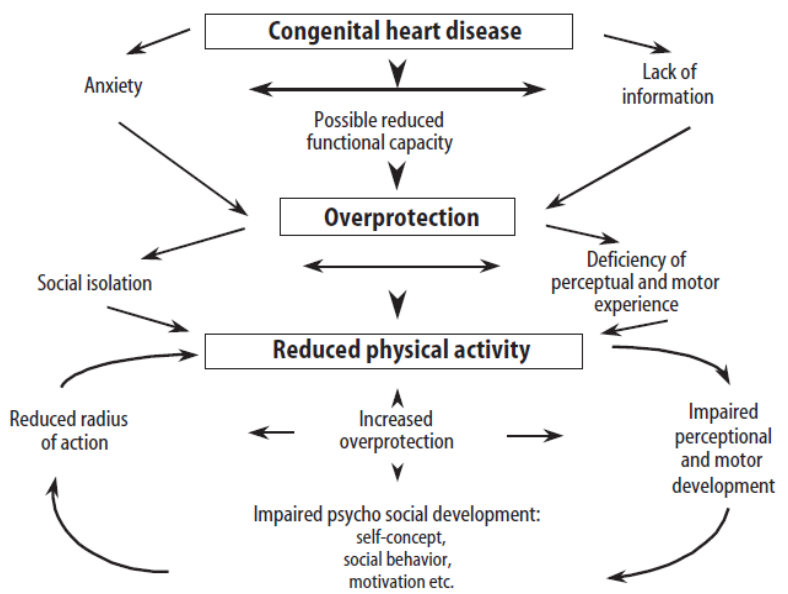

Gambar 1. Penyebab dan Dampak Aktivitas Fisik Pasien $\mathrm{PJB}^{14}$

\section{Penilaian Kapasitas Fungsional pada Anak PJB}

Penilaian kapasitas fungsional pada pasien dengan penyakit jantung adalah alat klinis penting untuk diagnosis, kuantifikasi gejala, prognosis dan evaluasi respon terhadap pengobatan. Beberapa tes tersedia untuk menilai kapasitas fungsional, tetapi penggunaannya pada anak-anak dan remaja dapat memberikan hasil yang berbeda dari yang diperoleh dari orang dewasa karena perbedaan dalam respon fisiologis dan metabolik terhadap stres. ${ }^{13}$ Puncak V02 merupakan indikator terbaik dalam menilai kapasitas fungsional status kardiopulmoner pada pasien PJB. Puncak VO2 adalah penyerapan oksigen tertinggi dicapai dalam interval 30 detik selama berolahraga. Ini mengekspresikan kapasitas daya tahan fungsional maksimal individu dan tergantung pada fungsi paru, kardiovaskular, dan otot. ${ }^{15}$ Pasien PJB yang dilakukan pemeriksaan dan didapatkan hasil Puncak VO2 $<15,5 \mathrm{ml} / \mathrm{kg} /$ menit ditemukan hanya $50 \%$ pasien yang memiliki angka bebas dari rawat inap dalam 2 tahun, sedangkan mereka yang memiliki puncak V02 lebih besar dari 27 $\mathrm{ml} / \mathrm{kg} /$ menit ditemukan mengalami bebas keluhan hinggal $97 \% .^{16}$

\section{Jenis uji latih}

Evaluasi dalam penilaian kapasitas fungsional dapat menggunakan beberapa cara seperti menggunakan cardiopulmonary exercise test (CPET), stress testing, atau six minutes walk test (6MWT). Peningkatan jumlah anak-anak dan remaja yang hidup dengan PJB dan peningkatan harapan hidup mereka harus mengarah pada kualitas hidup yang lebih baik. Ini termasuk kemampuan untuk melakukan aktivitas fisik normal, yang merupakan kualitas utama parameter kehidupan. ${ }^{17}$

Penilaian kapasitas fungsional menggunakan CPET masih belum direkomendasikan dalam bidang kardiologi pediatrik, walaupun saat ini semakin banyak ahli jantung pediatrik meresepkan CPET dalam tindak lanjut perawatan pasien. Pada penelitian yang dilakukan Pascal Amedro dkk tahun 2017 yang menilai kebugaran kardiopulmoner pada anak-anak dengan penyakit jantung bawaan versus anak-anak yang sehat menggunakan CPET dengan total sampel 798 anak didapati meskipun besarnya perbedaan tidak besar, VO2max di antara anak-anak dengan PJK secara signifikan lebih rendah daripada anak-anak normal. Sehingga peneliti menyarankan melakukan CPET dalam tindak lanjut rutin pasien ini. $^{5}$

Beberapa studi menggunakan 6MWT untuk evaluasi kapasitas fungsional pada pasien dengan PJB. 6MWT merupakan pemeriksaan yang murah dan mudah diterapkan dan terutama diindikasikan untuk mengukur respons selama perawatan. ${ }^{13}$

\section{Rehabilitasi Kardiovaskular Pada Anak PJB}

1. Prinsip Pemberian Latihan

Anak dengan PJB harus dapat mengikuti rekomendasi kesehatan dimana untuk dapat 
partisipasi sehari-hari dalam> 60 menit aktivitas fisik sedang hingga kuat yang sesuai perkembangan, dan melibatkan berbagai kegiatan. Selain itu, mereka harus melakukan aktivitas menetap kurang dari 2 jam/hari seperti menonton TV, menggunakan komputer, dan bermain video game. (Kelas I, tingkatan bukti B). Aktivitas fisik pada anak dengan PJB harus dinilai secara teratur. Untuk anak-anak, penilaian keterampilan motorik harus diselesaikan sampai anak telah mencapai semua keterampilan motorik dasar (biasanya sekitar 10 tahun). Keterampilan motorik dasar mencakup tidak hanya berjalan dan berlari, tetapi pola gerakan yang lebih lanjutan (seperti melompat tali, melompat melewati papan) serta keterampilan memanipulasi objek (misalnya melempar, menangkap, menendang). Beberapa aktivitas fisik yang dapat dilakukan oleh anak dengan PJB sama seperti aktivitas yang dapat dilakukan anak sehat pada umumnya seperti aktifitas aerobik yaitu berlari, melompat, lompat tali, berenang, menari, dan bersepeda. Aktivitas peregangan otot agar dapat membuat otot menjadi lebih kuat untuk melakukan lebih banyak aktivitas daripada biasanya selama aktivitas sehari-hari. Aktivitas peregangan otot dapat merupakan bagian dari permainan, seperti bermain di playground, angkat beban, menaiki tangga, bersepeda, dan bermain tarik-menarik Pengukuran obyektif dari aktivitas fisik harian pasien dibandingkan dengan laporan diri dari pasien atau keluarga harus dipertimbangkan dan pasien yang tidak mencapai tingkat aktivitas harian hingga sedang yang direkomendasikan harus ditawari untuk dilakukan konseling tambahan atau intervensi pelatihan sampai level aktivitas fisik yang dianjurkan dapat dicapai dan dipertahankan. (Kelas I, tingkat bukti C). ${ }^{11}$ Rekomendasi umum yang mengikuti prinsip FITT (Frequency, Intensity, Time, Type of activity) untuk kegiatan aktivitas fisik dan latihan olahraga pada anak-anak dan remaja ditunjukkan pada Tabel 1.
Tabel 1. Rekomendasi umum mengikuti prinsip FITT

\begin{tabular}{|c|c|c|c|}
\hline FITT & $\begin{array}{l}\text { Latihan } \\
\text { Aerob }\end{array}$ & $\begin{array}{l}\text { Interval } \\
\text { latihan }\end{array}$ & $\begin{array}{l}\text { Latihan } \\
\text { Kekuatan } \\
\text { Otot }\end{array}$ \\
\hline Frequency & $\geq 3 \mathrm{x} /$ minggu & $\geq 3 \mathrm{x} / \mathrm{minggu}$ & $\begin{array}{l}2-3 \\
x / \text { minggu }\end{array}$ \\
\hline Intensity & $\begin{array}{l}\text { Latihan } \\
\text { sedang } \\
\text { sampai berat } \\
\left(\mathrm{VO}_{2 \text { peak }} 40-\right. \\
85 \%)\end{array}$ & $\begin{array}{l}\text { 3-5 menit } \\
\text { dari dasar } \\
\text { latihan } \\
\text { ringan- } \\
\text { sedang } \\
\left(\mathrm{VO}_{2 \text { peak }} 20-\right. \\
59 \%)\end{array}$ & \\
\hline Time & 20-60 menit & $\begin{array}{l}\text { Total dalam } \\
60 \text { menit }\end{array}$ & $\begin{array}{l}\text { 2-3 menit } \\
\text { setiap } \\
\text { kelompok } \\
\text { otot (8-20 } \\
\text { repetisi) }\end{array}$ \\
\hline Type & $\begin{array}{l}\text { Lari, lompat, } \\
\text { bersepeda, } \\
\text { berenang, } \\
\text { sepakbola }\end{array}$ & $\begin{array}{l}\text { Lari, lompat, } \\
\text { bersepeda, } \\
\text { berenang }\end{array}$ & $\begin{array}{l}\text { Handgrips, } \\
\text { mendaki, } \\
\text { sit-up }\end{array}$ \\
\hline
\end{tabular}

\section{Rekomendasi Latihan}

Tingkat aktivitas fisik yang memadai bagi anak-anak dengan PJB sama pentingnya dengan anak-anak yang sehat. Namun, anak-anak dengan PJB mungkin kurang aktif daripada teman sebaya karena pembatasan yang berlebihan oleh orang tua dan pendidik. Sejumlah ahli telah memberikan rekomendasi mengenai olahraga untuk anak-anak dengan PJB. Rekomendasi ini dapat berkontribusi untuk mencegah pengecualian yang tidak perlu pada anak-anak dan remaja dengan penyakit jantung dari aktivitas fisik dan olahraga. Selain itu, dapat meminimalkan rasa tidak aman anak-anak, orang tua dan guru sehubungan dengan kemampuan fisik anak yang terkena dampak. Berdasarkan rekomendasi ini, semua anak dan remaja dengan PJB yang memenuhi persyaratan yang diperlukan harus memiliki kesempatan untuk berpartisipasi dalam aktivitas fisik dan jika perlu dapat turut ambil bagian dalam program pendidikan jasmani khusus.. Sebagai bahan pertimbangan dalam klasifikasi, kelainan jantung primer menjadi kurang penting daripada status klinis saat ini dan potensi komplikasi dari kelainan residual, pengelompokan berdasarkan kondisi jantung saat ini dan temuan paska operasi dapat dilihat pada tabel 2 dan 3.11,18-19 
Tabel 2. Klasifikasi Kondisi Pasien dengan Penyakit Jantung Bawaan.

\begin{tabular}{|c|c|}
\hline $\begin{array}{l}\text { Group } \\
0\end{array}$ & $\begin{array}{l}\text { Pasien dengan kelainan jantung yang } \\
\text { signifikan secara hemodinamik sebelum } \\
\text { operasi / intervensi jantung (termasuk ablasi) }\end{array}$ \\
\hline $\begin{array}{l}\text { Group } \\
1\end{array}$ & $\begin{array}{l}\text { Pasien setelah operasi jantung/operasi } \\
\text { intervensi catheter } \\
\text { 1.1 Tidak ada gejala sisa } \\
\text { 1.2 Dengan gejala sisa ringan } \\
\text { 1.3 Dengan gejala sisa signifikan } \\
\text { 1.4 Pasien dengan kelainan jantung } \\
\text { kompleks setelah intervensi paliatif } \\
\text { 1.4a Contoh : Operasi fontan atau Operasi } \\
\text { Mustard untuk TGA, dimana dimana } \\
\text { pemisahan sirkulasi sistemik dan paru } \\
\text { telah tercapai } \\
\text { 1.4b Pasien yang memiliki dua sistem } \\
\text { peredaran darah yang belum dipisahkan } \\
\text { (misalnya operasi shunt aortopulmoner) }\end{array}$ \\
\hline & $\begin{array}{l}\text { Pasien dengan kelainan jantung tanpa } \\
\text { membutuhkan operasi } \\
\text { 2.1. Lesi pirau dari kiri ke kanan yang tidak } \\
\text { signifikan seperti defek septum atrium atau } \\
\text { ventrikel kecil. } \\
\text { 2.2. kelainan katup yang tidak signifikan } \\
\text { seperti katup aorta bikuspid kongenital } \\
\text { 2.3. Aritimia yang tidak signifikan secara } \\
\text { klinis atau perubahan elektrokardiografi } \\
\text { 2.4. Perubahan miokard yang tidak signifikan } \\
\text { secara klinis. }\end{array}$ \\
\hline $\begin{array}{l}\text { Group } \\
3\end{array}$ & $\begin{array}{l}\text { Pasien dengan kelainan jantung yang tidak } \\
\text { bisa dioperasi }\end{array}$ \\
\hline $\begin{array}{l}\text { Group } \\
4\end{array}$ & Pasien dengan kardiomiopati kronis \\
\hline $\begin{array}{l}\text { Group } \\
5\end{array}$ & $\begin{array}{l}\text { 4.1 Signifikan secara klinis } \\
\text { 4.2 Tidak signifikan secara klinis } \\
\text { Pasien dengan masalah terapi jangka panjang } \\
\text { / permanen } \\
\text { 5.1 Pacemaker } \\
\text { 5.2 Antikoagulan } \\
\text { 5.3 Anti aritmia } \\
\text { 5.4 Anti Kongestif }\end{array}$ \\
\hline
\end{tabular}

Tabel 3. Rekomendasi Untuk Aktivitas Fisik Dan Olahraga

\begin{tabular}{llll}
\hline Group & Keparahan & \multicolumn{2}{l}{ Rekomendasi } \\
\hline 0 & Kelainan jantung yang & Tidak ada \\
membutuhkan operasi & olahraga & \\
A & $\begin{array}{l}\text { Tidak ada gejala sisa } \\
\text { Tak terbatas }\end{array}$ & & \\
& Koreksi komplit) & Tak terbatas \\
B & Gejala sisa ringan & Bukan olahraga \\
C & Gejala sisa signifikan & kompetitif \\
& secara klinis & Olahraga terbatas \\
D & Gejala sisa signifikan & & \\
& secara klinis yang berat & & Tidak \\
E & Temuan yang sangat & olahraga & \\
& mengancam & & \\
\hline
\end{tabular}

Kelompok ini mencakup semua anak dan remaja yang defek jantungnya telah dikoreksi baik pada saat bayi atau pada anak usia dini (patent ductus arteriosus, defek septum atrium kecil, defek septum ventrikel), yang tidak memiliki keterbatasan pada kapasitas olahraga (Grup 1.1). Bahkan pada pasien dengan cacat residu ringan (Grup 1.2) (seperti penyakit katup aorta sedang), beban normal dapat diperbolehkan dalam pendidikan jasmani dan aktivitas fisik di waktu senggang. Hal ini juga berlaku untuk anak-anak dan remaja yang cacat jantungnya tidak memerlukan pembedahan (Grup 2, misalnya, defek septum kecil atau stenosis valvular yang tidak signifikan). Kelompok pasien 1.1, 1.2 dan 2 memang memerlukan partisipasi sementara dalam program perbaikan dan / atau pendidikan jasmani yang diadaptasi jika ada pembatasan kebugaran fisik dan / atau defisit psikomotorik. Dalam konteks ini, indikasi untuk berpartisipasi dalam kelompok rehabilitasi berbasis latihan khusus juga dapat dihasilkan dari alasan psikososial. Pasien dengan kelainan jantung kompleks setelah operasi paliatif (Grup 1.4) merupakan kelompok kelompok khusus. Sebagian besar kelompok ini (Grup 1.4a), setelah tindakan menyebabkan tidak terjadinya sianotis yang menetap. Namun, beberapa pasien tetap pada kondisi sianotik (Grup 1.4b). Untuk kelompokkelompok ini, dan untuk anak-anak yang menerima terapi antikoagulan atau dengan alat implan (alat pacu jantung, ICD) atau dengan risiko kematian mendadak, rekomendasi khusus terhadap masing masing individu harus dibuat. ${ }^{19}$

3. Rekomendasi latihan pada lesi jantung bawaan spesifik

A. Isolated shunt defects (atrial septal defect, ventricular septal defect, patent duct arterial)

Pada pasien dengan defek septum atrium (ASD), darah dikeluarkan dari atrium kiri ke kanan. Pada defek yang kecil, jumlah total darah dapat diabaikan. Pada defek yang lebih besar dapat menyebabkan volume ventrikel kanan terlalu banyak dan mungkin menyebabkan hipertensi pulmonal selama berolahraga. Banyak pasien akan memiliki kapasitas olahraga yang sedikit berkurang. Setelah penutupan, kapasitas latihan pasien akan meningkat dan kembali pada kondisi normal. Residual hipertensi pulmonal atau aritmia sangat jarang terjadi selama masa kanakkanak. Oleh karena itu, tidak ada batasan untuk aktivitas fisik atau latihan olahraga untuk kelompok pasien ini. Ini berlaku untuk leisure 
sports dan kegiatan fisik lainnya. Setelah intervensi penutupan ASD menggunakan alat, pasien harus melanjutkan aktivitas olahraga ringan segera setelah lokasi tusukan di pangkal paha sembuh sepenuhnya (10-14 hari setelah intervensi). Olahraga kontak harus dihindari selama 6 bulan sampai perangkat benar-benar tertutup oleh endokardium, dan risiko dislogement menjadi minimal. Setelah penutupan secara operasi menggunakan patch , tidak ada batasan setelah penyembuhan luka sternotomi.10 Anak-anak dengan VSD (diperbaiki atau tidak diperbaiki) harus didorong untuk aktif dan mengadopsi gaya hidup sehat. Jika kapasitas olahraga tidak normal, anak-anak dengan VSD harus disarankan untuk terlibat dalam program latihan fisik. Setelah penutupan VSD intervensi atau bedah, rekomendasi yang sama berlaku seperti setelah penutupan ASD termasuk pada pasien yang telah dilakukan penutupan PDA. ${ }^{11}$

Rekomendasi leisure sport dan aktivitas fisik harian. Selama tidak ada aritmia yang disebabkan oleh aktivitas ataupun olahraga, disfungsi miokard istirahat, atau hipertensi pulmonal, tidak ada alasan bagi anak-anak ini untuk tidak melakukan aktivitas secara normal dalam latihan fisik. (Kelas I, tingkat bukti C). Tidak ada batasan untuk kegiatan olahraga kompetitif. Keterbatasan untuk olahraga kompetitif hanya pada pasien dengan hipertensi arteri pulmonalis. (Kelas I, tingkat bukti C). 10

\section{B. Penyakit katup aorta}

Pada pasien dengan stenosis aorta valvular, terdapat data tentang kejadian kematian mendadak selama aktivitas olahraga. Sekitar 2-4\% dari semua atlet muda dengan kematian jantung mendadak ditemukan memiliki stenosis katup aorta. Anak-anak dengan stenosis aorta ringan dapat diikutsertakan dalam semua jenis leisure sport atau olahraga kompetitif, tetapi harus menjalani evaluasi serial tingkat keparahan stenosis aorta setidaknya setiap tahun. Sedangkan pada anak dengan stenosis. Anak-anak dengan regurgitasi aorta ringan atau sedang tidak boleh dibatasi dari aktivitas fisik apa pun selama tidak ada dilatasi ventrikel kiri (LV), dilatasi / aneurisma aorta, atau aritmia. (Kelas I, tingkat bukti C). ${ }^{10}$

\section{Koarktasioa Aorta}

Terdapat penurunan kapasitas olahraga meskipun setelah perbaikan koarktasio aorta, dibandingkan dengan setelah perbaikan bedah kelainan jantung kongenital lainnya. Mekanisme yang mungkin termasuk adanya disfungsi vaskular yang berkaitan dengan berkurangnya elastisitas aorta, penurunan fungsi arteriolar dan peningkatan refleks baroreseptor. Temuan yang mengejutkan pada saat berolahraga pada banyak pasien koarktasio adalah peningkatan tekanan darah sistolik yang tidak proporsional, disebabkan oleh restenosis minor dan oleh pengerasan dinding aorta. ${ }^{10}$

Masih rendahnya penelitian mengenai leisure sport atau latihan fisik pada pasien koarktasio aorta baik sebelum dan setelah perbaikan. Pasien koarkulasi aorta yang terisolasi tanpa residual gradien yang signifikan di lokasi koarktasio $(<20$ mmHg)22, tanpa peningkatan tekanan darah sistolik yang berlebihan saat berolahraga dan tanpa aneurisma cerebral atau aneurisma aorta dapat berpartisipasi dalam semua jenis kegiatan olahraga kecuali mereka dengan komponen statis yang sangat tinggi. (Kelas IIa, tingkat bukti C). ${ }^{10}$

\section{Tetralogy of Fallot}

Pasien tetralogy of fallot yang tanpa gejala dengan ditemukan regurgitasi pulmonal yang tidak signifikan dan dilatasi RV normal / ringan, dengan tekanan ventrikel kanan yang normal, fungsi sistolik normal, tidak ditemukan aritmia pada pemantauan EKG atau tes latihan harus didorong untuk dapat terlibat dalam aktivitas fisik dengan tingkat dan intensitas yang sama pada anak sehat umumnya. Pasien yang menunjukkan gejala dengan upaya ringan atau sedang, obstruksi right ventricle outflow tract, disfungsi ventrikel kiri, adanya tanda-tanda peningkatan tekanan ventrikel kanan atau peningkatan gradien transpulmonary, residual shunt intrakardiak signifikan yang tidak dapat dikoreksi, dan pasien dengan aritmia hanya dapat melakukan latihan fisik terbatas dengan intensitas yang rendah (Kelas I, tingkat bukti C). ${ }^{10}$

Pasien yang telah dilakukan koreksi dan memiliki tekanan ventrikel kanan normal atau mendekati normal, tidak ada atau hanya kelebihan volume ventrikel yang ringan, tidak ada residual shunt yang signifikan, dan tidak ada aritmia pada pemantauan EKG rawat jalan atau dapat 
berpartisipasi dalam semua olahraga dengan intensitas apa pun. Namun aktivitas terbatas pada olahraga anerob dan aerob intensitas yang sedang. (Kelas I, tingkat bukti C). ${ }^{10}$

\section{Simpulan}

Semua anak memiliki kebutuhan alami untuk bergerak, bermain, dan melakukan aktivitas. Aktivitas fisik diperlukan untuk perkembangan fisik, emosi, dan psikososial optimal baik pada anak yang sehat maupun anak dengan penyakit jantung bawaan. Anak yang dilakukan pembatasan terhadap aktivitas akan berdampak mengalami gangguan fisik, motorik, kognitif, serta masalah pada lingkungan sosial sehingga tidak semua anak dengan penyakit jantung bawaan tidak boleh atau dilakukan pembatasan terhadap aktivitas fisik atau latihan olahraga. Anak dengan penyakit jantung bawaan dapat dimulai rehabilitasi kardiovaskular dimulai dari saat terdiagnosis hingga anak telah dilakukan koreksi baik secara bedah maupun penutupan dengan alat.

\section{Daftar Pustaka}

1. Bhatt AB, Foster E, Kuehl K, Alpert J, Brabeck S, Crumb $S$, et al. Congenital heart disease in the older adult: a scientific statement from the American Heart Association. Circulation. 2015;131:1884-931.

2. Macmahon B, McKeown $\mathrm{T}$ and Record RG. The incidence and life expectation of children with congenital heart disease. Br Heart J. 1993;15:121-9.

3. Tikkanen AU, Oyaga AR, Riano OA, Alvaro EM and Rhodes J. Paediatric cardiac rehabilitation in congenital heart disease: a systematic review. Cardiol Young. 2012;22:241-50.

4. Van der Bom T, Zomer AC, Zwinderman AH, Meijboom FJ, Bouma BJ and Mulder BJ. The changing epidemiology of congenital heart disease. Nat Rev Cardiol. 2011;8:50-60.

5. Amedro P, Gavotto A, Guillaumont S, Bertet H, Vincenti $\mathrm{M}$, De La Villeon G, et al. Cardiopulmonary fitness in children with congenital heart diseases versus healthy children. Heart. 2018;104:1026-1036.

6. Feltez G, Coronel CC, Pellanda LC and Lukrafka JL. Exercise capacity in children and adolescents with corrected congenital heart disease. Pediatr Cardiol. 2015;36:1075-82.

7. Schaan CW, Feltez G, Schaan BD and Pellanda LC. Functional Capacity in Children and Adolescents with Congenital Heart Disease. Rev Paul Pediatr. 2019;37:65-72.

8. Fredriksen PM, Ingjer F, Nystad $\mathrm{W}$ and Thaulow E. A comparison of VO2(peak) between patients with congenital heart disease and healthy subjects, all aged 8-17 years. Eur J Appl Physiol Occup Physiol. 1999;80:409-16.

9. Rhodes J, Ubeda Tikkanen A and Jenkins KJ. Exercise testing and training in children with congenital heart disease. Circulation. 2010;122:1957-67.
10. Piercy KL, Troiano RP, Ballard RM, Carlson SA, Fulton JE, Galuska DA, et al. The Physical Activity Guidelines for Americans. JAMA. 2018;320:2020-2028.

11. Takken T, Giardini A, Reybrouck T, Gewillig M, HovelsGurich HH, Longmuir PE, et al. Recommendations for physical activity, recreation sport, and exercise training in paediatric patients with congenital heart disease: a report from the Exercise, Basic \& Translational Research Section of the European Association of Cardiovascular Prevention and Rehabilitation, the European Congenital Heart and Lung Exercise Group, and the Association for European Paediatric Cardiology. Eur J Prev Cardiol. 2012;19:1034-66.

12. Bjarnason-Wehrens B, Sigrid D, Narayanswami S, Brockmeier $\mathrm{K}$, Mathes $\mathrm{P}$, Monpère $\mathrm{C}$, et al. Cardiac Rehabilitation in Congenital Heart Disease. Cardiovascular Prevention and Rehabilitation. 2007:361-373.

13. Schaan CW, Feltez G, Schaan BD and Pellanda LC. Functional Capacity in Children and Adolescents with Congenital Heart Disease. Rev Paul Pediatr. 2018;37:65-72.

14. Bjarnason-Wehrens B, Dordel S, Schickendantz S and Sreeram N. Exercise training in congenital heart disease. Cardiac rehabilitation manual. 2017;2:257285.

15. Mantegazza V, Apostolo A and Hager A. Cardiopulmonary Exercise Testing in Adult Congenital Heart Disease. Ann Am Thorac Soc. 2017;14:S93-S101.

16. Diller GP, Dimopoulos K, Okonko D, Li W, BabuNarayan SV, Broberg CS, et al. Exercise intolerance in adult congenital heart disease: comparative severity, correlates, and prognostic implication. Circulation. 2005;112:828-35.

17. Marelli AJ, Mackie AS, Ionescu-Ittu R, Rahme E and Pilote L. Congenital heart disease in the general population: changing prevalence and age distribution. Circulation. 2007;115:163-72.

18. Hirth A, Reybrouck T, Bjarnason-Wehrens B, Lawrenz W and Hoffmann A. Recommendations for participation in competitive and leisure sports in patients with congenital heart disease: a consensus document. Eur J Cardiovasc Prev Rehabil. 2006;13:293-9.

19. Schickendantz S, Sticker EJ, Dordel S and BjarnasonWehrens B. Sport and physical activity in children with congenital heart disease. Deutsches Arzteblatt. 2007;104:563-569. 